\title{
Czym jest i po co jest krytyka? O możliwościach i granicach krytyki feministycznej dzisiaj ${ }^{1}$
}

\section{Sabine Hark}

Technische Universität Berlin

\begin{abstract}
Artykut oparty jest na filozoficznych rozważaniach na temat potencjału dzisiejszej krytycznej teorii feministycznej. Autorka traktuje krytykę feministyczna jako projekt służący wyjaśnianiu relacji między wiedza, władza $i$ sposobami bycia, oraz jako praktykę sprawdzania reżimów zrozumiatości, które dyktują, co jest możliwe do zrealizowania, a co nie jest.
\end{abstract}

Stowa kluczowe: feminizm, krytyka, reżimy zrozumiatości, władza, wiedza, sposoby bycia, wykluczenie, uznanie

\section{1. Śmierć przez oznajmienie ${ }^{2}$ - prolog}

[...] pierwszy raz w historii naszego kraju córka wykształconego Anglika jest w stanie, w odpowiedzi na prośbę swego brata, ofiarować mu [...] własną, samodzielnie zarobioną gwineę, nie domagając się niczego w zamian. Daje mu ją z wolnej i nieprzymuszonej woli - nie ze strachu ani z chęci przypodobania lub uzyskania czegoś dla siebie. Przyzna Pan chyba, iż tak przełomową chwilę w historii cywilizacji należałoby jakoś uczcić. [...] Sytuację tak nową trzeba uczcić w nowy sposób. Najlepiej, niszcząc przestarzałe, fałszywe i zdeprawowane słowo, które w swoim czasie wyrządziło wiele złego, a dziś straciło rację bytu. Mam na myśli słowo "feministka". Według słownika "feministka" to "osoba domagająca się przyznania kobietom równych praw". Ale ponieważ jedyne prawdziwe prawo, prawo do zarabiania na życie, już posiadamy, więc tamto słowo straciło sens. A słowo, które straciło sens, staje się słowem martwym i zaczyna się rozkładać. Dla uczczenia naszego święta urządźmy mu całopalenie. Wypisujemy martwe słowo "feministka" wielkimi literami na arkuszu kancelaryjnego papieru i uroczyście przykładamy zapałkę. Popatrzcie, jak płonie! Jakie rzuca błyski! A potem rozcieramy popiół w moździerzu gęsim piórem i ogłaszamy wszem i wobec, iż każdy, kto ośmieli się to słowo jeszcze raz wymówić, zostanie uznany za tchórza, który po naciśnięciu dzwonka ucieka spod drzwi ${ }^{3}$ - za prowokatora, grzebiącego w zetlałych kościach, śmieciarza z wypisanym

\footnotetext{
${ }^{1}$ Za cenne uwagi do tego przekładu tekstu dziękuję Agnieszce Kowaluk. Za krytyczną lekturę mojego przekładu również dziękuję Redakcji InterAlia oraz za jej zaangażowanie w umożliwieniu opublikowania tego tekstu. (Anna Kasten, tłumaczka)

2 Sabine Hark używa w swoim tekście angielskiego wyrażenia death by report.

${ }^{3} \mathrm{~W}$ oryginale "a ring-the-bell-and-run-away-man" - zbitka słowa utworzona przez Virginię Woolf na określenie osoby, która celowo używa krzywdzących słów, udając, że nie robi nic złego.
} 
na czole brudnym piętnem nikczemnika. Dym się rozwiał, słowo przestało istnieć. Zobaczymy, co z naszej uroczystości wynikło. Zniknięcie słowa "feministka" sprawiło, że powietrze stało się przejrzyste. I co w tej przejrzystości widzimy? Mężczyzn i kobiety zmierzających razem do wspólnego celu. Znad przeszłości też podniosła się mgła. O co bowiem walczyły w XIX wieku nieżyjące już kobiety ${ }^{4} \mathrm{w}$ dziwacznych kapeluszach z podwiniętym rondem i długich szalach? O to samo, o co my dzisiaj walczymy. Oddaję głos Josephine Butler: „Walczyłyśmy nie tylko o równouprawnienie kobiet, lecz o sprawę o wiele szerszą i głębszą - o powszechne równouprawnienie wszystkich, zarówno kobiet, jak i mężczyzn, o poszanowanie, w ich osobach, wielkich zasad Wolności, Równości i Sprawiedliwości”5. Josephine Butler walczyła o to samo, o co Pan dzisiaj walczy; mówiła tymi samymi, co Pan, słowami. [...] A zatem nasza obecna walka jest jedynie przedłużeniem tej, którą toczyły nasze matki i nasze babki [...]. (Woolf 2002: 277n.)

Powyższy fragment pochodzi ze słynnego eseju Virginii Woolf Trzy gwinee (1936; pl. 2002), poświęconemu kwestii, jaką różnicę stanowi w życiu kobiet i mężczyzn dysponowanie własnym dochodem. Nie jest to pierwsza, choć w swej ostrej a jednocześnie wyjątkowo subtelnej ironii zapewne jedna z najbardziej błyskotliwych i niedoścignionych wersji wysoce ambiwalentnego gatunku, jakim jest "nekrolog feminizmu”.

Woolf proponuje przede wszystkim rozwiązanie problemu, który i dzisiaj dręczy klienciary ${ }^{6}$, post-, pop- i alfa-feministki, oraz który pomimo różnorodności, a nawet sprzeczności stanowisk, łączy je częściowo z pozycjami antyfeministycznymi: w jaki sposób, w imię własnej wersji feminizmu, pozbyć się (starego) feminizmu i co zrobić ze słowem na "f"?

Propozycja Woolf wydaje się radykalna: słowo na "f" trzeba spalić. Ponieważ nigdy nie będzie ono w stanie uwolnić się od przyległych ośmieszających, uwłaczających znaczeń, ostatecznie zaszkodzi zarówno sprawie feministycznej w rozumieniu Woolf, jak i walce o "poszanowanie tych wielkich zasad Sprawiedliwości i Równości, i Wolności" każdej osoby. Jednak sposób, który sugeruje Woolf, tj. pozbycie się zwłok feminizmu przez dosłowne i symboliczne spalenie słowa na "f", to coś innego, coś więcej niż tylko propozycja ceremonii pogrzebowej. Woolf korzysta tu z określonego toposu, aby podkreślić jego wieloznaczność w takim stopniu, by zaczął przeczyć sam sobie, z toposu prawdopodobnie tak starego jak sam feminizm, z toposu towarzyszącemu mu, w bardzo różnych intencjach, od samego początku. Jest to topos śmierci przez oznajmienie, czyli usunięcie feminizmu przez oznajmienie jego śmierci.

\footnotetext{
${ }^{4} \mathrm{~W}$ oryginale angielskim kobiety są określone jako "queer" (A.K.).

${ }^{5}$ Josephine Butler (1828-1906).

${ }^{6}$ Sabine Hark używa pojęcia "Spartenfeministinnen”, co oznacza, że tylko pewna klientela jest adresowana. W tym sensie można używać zwrotu "feminizm klientelistyczny" (A.K.).
} 
Woolf wyraźnie podkreśla aktualną do dnia dzisiejszego funkcję tego toposu: aby następne pokolenia mogły korzystać z owoców walk feministycznych poprzednich pokoleń (lecz tak, aby nie było jasne, że chodzi o walki feministyczne), aby mógł powstać nowy feminizm (za każdym razem ogłaszany jako mniej sekciarski, mniej separatystyczny niż jego poprzednik i w żadnym razie niewykluczający mężczyzn), ale też, aby feminizm można było określić jako nieistotny, niepotrzebny, zbędny lub wręcz groźny i niebezpieczny, aby usunąć go poza granice aktywnej recepcji współczesnych, trzeba go nieustannie rytualnie poświęcać, a jego przedwczesny zgon - zazwyczaj rzekomo z własnej winy lub z powodu nieuleczalnych chorób, takich jak dogmatyzm, wrogość wobec pożądania bądź separatyzm - regularnie oznajmiać.

Uznać feminizm za zmarły oznacza scharakteryzować niezależny feministyczny aktywizm jako ogólnie obcy dla żyjących [...] jako sposób istnienia, który jest tak odmienny, że w obrębie "naszej" wspólnoty nie może być tolerowany [...] Ogłoszenie, że feminizm nie żyje, przekreśla walki kobiet o sprawiedliwość na całym świecie, podczas gdy ślady tego wymazywania są równocześnie zacierane.

- tak dynamikę śmierci przez oznajmienie komentuje amerykańska teoretyczka feminizmu Mary Hawkesworth. Podobny komentarz znajdziemy u brytyjskiej kulturoznawczyni feministycznej, Angeli McRobbie: „żeby feminizm mógł być traktowany poważnie, trzeba go uznać za zmarły” (2003: 657). Woolf używa toposu śmierci przez oznajmienie najpierw mimetycznie, a wręcz afirmatywnie:

Najlepiej, niszcząc przestarzałe, fałszywe i zdeprawowane słowo, które w swoim czasie wyrządziło wiele złego, a dziś straciło rację bytu. Mam na myśli słowo "feministka". Według słownika "feministka" to "osoba domagająca się przyznania kobietom równych praw". Ale ponieważ jedyne prawdziwe prawo, prawo do zarabiania na życie, już posiadamy, więc tamto słowo straciło sens. A słowo, które straciło sens, staje się słowem martwym i zaczyna się rozkładać. Dla uczczenia naszego święta urządźmy mu całopalenie. (Woolf 2002: 277)

Może się zdawać, że Woolf podziela pogląd, iż równe prawa dla kobiet są już zagwarantowane: najważniejsze prawo - do zarabiania na własne utrzymanie - zostało osiągnięte. Tym samym feminizm stał się zbędny. Jednak Woolf idzie jeszcze dalej: jej zdaniem feminizm jest słowem niebezpiecznym, słowem, które przyniosło wiele cierpienia. Co więcej, dziś (w 1938 r., S. H.) jest to słowo zepsute, wręcz zdegenerowane i skorumpowane, ponieważ sam feminizm nie dostrzega własnego braku znaczenia. Ale kiedy jesteśmy już niemal skłonni uwierzyć, że Woolf naprawdę myśli to, co pisze, robi ona nagły zwrot. Kiedy tylko dym się rozejdzie, pisze dalej Woolf, widzimy lepiej sens rzeczy: słowo "feminizm" może i zniszczono, ale dzięki temu uzyskano wyraźny, przejrzysty widok sytuacji obecnej i przeszłej. Widać, że nie tylko teraz kobiety i mężczyźni działają na rzecz Sprawiedliwości, Równości i Wolności; widać także, że te "kobiety w dziwnych kapeluszach", owe "queer dead 
women in their poke bonnets and shawls" wcale nie są tak dziwaczne i niepoważne, jak się je przedstawia, ponieważ walczyły w tej samej sprawie, w którą do dzisiaj, a więc do czasów Woolf, angażują się kobiety i mężczyźni.

\section{Polityka i etos opowiadania}

Być może nie od razu widać, co użycie toposu śmierci przez oznajmienie może dzisiaj wnieść do dyskusji o możliwościach krytyki feministycznej i jej granicach - a krytyka feministyczna ma być tu rozumiana jako projekt krytyki związku między władzą, wiedzą i sposobami istnienia. Moim zdaniem zrozumienie dynamiki tego toposu stanowi zarówno jeden z warunków wstępnych krytyki feministycznej, jak i jeden z jej głównych przedmiotów. Stopień, w jakim topos ten reguluje akceptację poglądów i postaw feministycznych jako "rozsądnych" czy "odpowiednich" w opinii publicznej, jest istotnym czynnikiem decydującym o strukturze przestrzeni dla możliwości krytyki feministycznej. Co więcej, wpływa on na określenie, która forma feminizmu jest dopuszczalna w granicach "naszych" społeczności, jak wyobrażamy sobie przyszłość feminizmu i jak mówimy (możemy mówić) o jego przeszłości. A szczególnie istotne jest to w obecnej sytuacji, w której z jednej strony siły post-2ndwave i siły antyfeministyczne pracują nad przeformułowaniem feminizmu w elitarny, "odgórny", solipsystyczny, heteronormatywnie ugruntowany projekt; zaś z drugiej strony te same siły aktywnie obracają jego dezartykulację w wielowymiarową, glokalną, polifoniczną, a często także niespójną, wewnętrznie sprzeczną kolektywną, "oddolną" praktykę polityczną.

Spójrzmy na obecny kontekst: z jednej strony mamy historyczne zacieranie feminizmu i mniej lub bardziej subtelne przepisywanie jego historii ${ }^{7}$, jak również aktywne spychanie w niebyt globalnego, antyimperialistycznego aktywizmu feministycznego, z drugiej zaś konkurujące ze sobą kolonizacje na terytorium feministycznej wiedzy, wyposażone w nierówny kapitał negocjacyjny, a działające w sojuszu $\mathrm{z}$ aktualnymi zinstytucjonalizowanymi praktykami politycznymi, takimi jak gender mainstreaming $\mathrm{i}$ managing diversity. Stąd obecny moment ma szczególne znaczenie dla przedsięwzięcia, o które mi tutaj chodzi, to jest dla stworzenia krytycznej feministycznej wiedzy w świecie akademickim. Feminizm po raz pierwszy w swojej historii występuje jako część nauki, instytucji o dużym wpływie na społeczeństwo, przez co staje się, przynajmniej pod pewną postacią, stałą częścią tej instytucji, której społeczeństwo (jeszcze) przypisuje niemal autorytatywną władzę definiowania i która tworzy najbardziej wpływową dla naszych społeczeństw wiedzę, mianowicie wiedzę naukową. ${ }^{8}$ Jednak tym samym feminizm staje wobec konieczności znalezienia odpowiedzi na pytanie, w jaki sposób połączyć w

\footnotetext{
${ }^{7}$ Angela McRobbie w The Aftermath of Feminism (2008) rekonstruuje proces zapisu w następujący sposób: „Pewne elementy feminizmu są uchwycane i wyraźnie integrowane do życia politycznego i w szereg instytucji społecznych. Przy zastosowaniu słów jak »społeczno-kulturowe upodmiotowienie« (empowerment) i »wolność wyboru« (choice) zostały te elementy przekształcone w znacząco bardziej indywidualistyczny dyskurs. W nowym przebraniu zostają one używane jako forma feminizmu-zastępczego, przede wszystkim w mediach i kulturze popularnej, ale także w instytucjach państwowych. Związane z tym nowe i rzekomo „współczesne” wyobrażenia na temat kobiet, zwłaszcza młodych kobiet, zostają w agresywny sposób w ich celu rozprzestrzeniane, aby zapobiec powstaniu nowego ruchu kobiecego." (McRobbie 2009, 1; tłumaczenie na niemiecki S.H.)

${ }^{8}$ Sabine Hark szczegółowo zajęła się tą kwestią w Dissidente Partizipation. Eine Diskursgeschichte des Feminismus (2005).
} 
sobie intelektualną i społeczną krytykę feministyczną, jeśli prawdą jest, że krytyka występuje tylko tam, "gdzie społeczne machiny oporu są nierozerwalnie związane z machinami tekstu" (Raunig 2008: 9).

Feminizm akademicki, jako część instytucji akademickiej, jest potencjalnie silnym graczem w ważnej grze o ustanowienie własnej wizji każdego z uzasadnionych podziałów świata, a zatem spoczywa na nim szczególna społeczna odpowiedzialność. Przede wszystkim ma on szansę przeciwdziałać owemu historycznemu wymazywaniu feminizmu, jego dezartykulacji, ponieważ - jako część instytucji, której funkcją jest tworzenie i rozpowszechnianie wiedzy - może w naszych budowanych na wiedzy społeczeństwach brać udział w tworzeniu zbiorowej pamięci. Oznacza to, że instytucje rozstrzygają, co będzie zapamiętane, a co zapomniane. Jak argumentuje Mary Douglas w Jak myśla instytucje (2011), "style myślowe" nadają - w zależności od swoich własnych instytucji - „kształt światu myśli, sterując jego pamięcią" (Douglas 2011: 82). "Styl myślowy”, twierdzi Douglas, "stanowi warunek konieczny wszelkiego poznania i to on decyduje, co można uznać za rozsądne pytanie albo prawdziwą lub fałszywą odpowiedź" (5). Oznacza to, że feminizm akademicki wytwarza nie tylko po prostu "feministyczną pamięć", jak argumentuje Heike Kahlert (2001: 91), ale pamięć feministyczną rządzoną przez instytucję i jej styl myślowy, co z kolei ustala możliwości krytyki feministycznej, określając, co uchodzi za "rozsądną" wypowiedź feministyczną i czyjego głosu warto słuchać.

Stawką jest zatem tylko i aż przeszłość i przyszłość projektu feministycznego. Przeszłość nie jest bowiem dana raz na zawsze, ale jest tworzona wciąż na nowo zgodnie z regułami hegemonicznego stylu myślowego. A przyszłość jest zawsze już ukształtowana przez metody opowiadania o przeszłości. W jakiej zatem postaci zachowa się feminizm w zbiorowym postrzeganiu i zbiorowej pamięci: jako ta część projektu modernistycznego, która zakorzeniona jest w kantowskiej tradycji Oświecenia, która nie tylko pyta "co teraz?", ale pojmuje siebie także jako opór wobec (nieuprawnionego) autorytetu, jako opór wobec niebycia tak rządzonym, jako praktykę wolności oraz jako oddolny ruch społeczny? Czy jako projekt politycznego uprzywilejowania określonej klasy kobiet kosztem wszystkich innych - także kosztem niektórych mężczyzn? I w jakiej postaci zapamiętamy feminizm akademicki?

Czy jako zwyczajną dyscyplinę naukową, która ma swoje korzenie w dziewiętnastowiecznym Pragnieniu unormowania natury, świata i społeczeństwa oraz tworzenia „porządku rzeczy” (Foucault 1971) przez naukę porządku istnienia? Czy jako praktykę intelektualną, która o tyle wiąże się z krytyką społeczną, że poszukuje nowych sposobów opisania życia? Która więc, cytując Judith Butler, ma odwagę wzniecić "bunt na poziomie ontologii” i stawia pytanie, czyje życie jest prawdziwe i jak można na nowo tworzyć rzeczywistość (Butler 2005: 50)? A jeśli nasza strategia opowiadania o przeszłości zawiera przede wszystkim to, jak chciałybyśmy i chcielibyśmy być zapamiętani, czyli jeśli koncentrujemy się na tym, jak powinna wyglądać wyimaginowana przyszłość, a nie na "dokładności” opisu tego, co minione - to jakie możliwości otwieramy, a jakie wykluczamy? Jaką więc przyszłość damy "temu" feminizmowi? 
Obecnie dyskusja o możliwościach i ograniczeniach krytyki feministycznej w kontekście akademickiego tworzenia wiedzy musi rozpocząć się od refleksji na temat polityki i etosu własnych opowiadań: jak oddać sprawiedliwość politycznej, teoretycznej i naukowej historii feminizmu nie rezygnując z własnej/ych historii w ciągłym przerzucaniu się indywidualnymi opowieściami? Nie sytuując feminizmu w pozycji trupa, a przynajmniej ciała anachronicznego, przestarzałego, którego czas dawno minął? Nie trzymając się kurczowo jego bohaterskich momentów, a tym samym nie zmuszając go do wiecznego powtarzania samego siebie? Jak możemy sprostać historyczności własnego myślenia, wybronić się przed nostalgią czy konserwatyzmem „w oparciu o fundamentalną wieloznaczność tego, co społeczne" (Laclau i Mouffe 2007: 179), kiedy ze względu na „niemożność ostatecznego ustalenia znaczenia każdej walki" (179) nic nie chroni myśli przed jej dyskursywnym - i instytucjonalnym kontekstem zewnętrznym, który ją przekształca?

Zadawanie tych pytań jest konieczne dlatego, że topos śmierci przez oznajmienie może pojawić się w nieskończonej liczbie postaci, także w formie owego rzekomego starzenia się lub nieadekwatności stanowisk teoretycznych feminizmu, bądź w formie ośmieszających lub umniejszających przedstawień "wcześniejszych" pozycji feministycznych. W każdym razie dość często na pierwszy plan wysuwa się chęć ugruntowania własnej pozycji zamiast prób krytycznych dyskusji na temat zakresu i ograniczeń stanowisk teoretycznych, zamiast krytycznej rekonstrukcji rozgałęzień i wzajemnych połączeń dyskursu, zamiast odtworzenia historii teorii feministycznej jako historii zawsze złożonego pola sprzecznych i nieporównywalnych pozycji teoretycznych, jako „produktywnego pola napięcia koncepcyjnie różnych ruchów myślowych" (Genschel 2002: 166).

\section{Nie być tak rządzonym! Etos tworzenia wiedzy}

Stawka jest jednak znacznie większa niż polityka i etos opowiadań. Stawką jest przede wszystkim to, co możemy nazwać etosem tworzenia wiedzy feministycznej, czyli to, jak feministyczne tworzenie wiedzy chce być rządzone i jak chce się rządzić samo. Pytanie o etos tworzenia wiedzy jest szczególnie ważne, jeśli krytykę feministyczną rozumiemy jako praktykę teoretyczną skupiającą się na związku pomiędzy władzą, wiedzą i (możliwymi) sposobami istnienia, i mającą odwagę wzniecić owy „bunt na poziomie ontologii"; jeśli rozumiemy ją jako praktykę przepytywania reżimów zrozumiałości, czyje i które (płciowe i seksualne) istnienie i głos dominujący porządek postrzegania (także wiedzy feministycznej) dopuszcza, a czyj i który odrzuca. Pytanie brzmi więc: jakiemu stylowi myślowemu, jakiemu dominującemu porządkowi postrzegania pozwoli w przyszłości rządzić się feminizm (akademicki), a jaki porządek sam się wygeneruje. Innymi słowy, ważne jest pytanie w ramach jakiego porządku racjonalności - rozumianego jako zgodność zasad, procedur, sposobów zachowania i myślenia, przy uwzględnieniu wszystkich warunków koniecznych w danym momencie do rozwiązania określonych zadań - chce działać feminizm? Które fikcje racjonalności - wzory decyzji uchodzące w społeczeństwie za racjonalne ${ }^{9}$ - mają organizować myślenie feministyczne? Które pytania zostaną uznane za rozsądne, a które odpowiedzi za prawidłowe? Jaką wiedzę, jakie praktyki i jakie horyzonty odnaj-

\footnotetext{
${ }^{9} \mathrm{~A}$ ci, którzy orientują się na tych wzorach, z punktu widzenia wszystkich nie robią nic niewłaściwego.
} 
dziemy pod nazwą feminizmu w przyszłości? Jakimi wartościami będzie się kierować feministyczne tworzenie wiedzy? Na jakich epistemicznych granicach zatrzymywać? Z jakich pozycji10 pisać? I wreszcie: komu i na jakie pytania odpowiada wiedza feministyczna? Przed kim ponosimy odpowiedzialność i jaki jej zakres uznajemy? Innymi słowy, kogo uwzględniamy w wiedzy feministycznej i przy jej pomocy?

Jak więc tworzyć krytyczna wiedzę w kontekście i w granicach porządku racjonalności instytucji, której sądy obecnie należą do ludzi najbardziej wpływowych w społeczeństwie? Instytucji, której celem może być nie zmiana, ale raczej utrzymanie w stanie nienaruszonym istniejących kultur, seksualności i relacji władzy, upłciowionych i rasizowanych, odwołujących się do narodu, klasy i umiejscowienia geopolitycznego, a także do kultury i seksualności. Jeśli ten opis choćby tylko w części odpowiada prawdzie, to trzeba dokładnie zrozumieć procesy, które ukonstytuowały akademicko uprzywilejowany a równocześnie marginalizowany podmiot - marginalizowany w formie okresowo nieciągłych, ale powiązanych rejestrów (między innymi) seksualności i płci oraz poprzez nie; jednocześnie trzeba stawić opór tym procesom. To pomoże wyjaśnić, jak można w kontekście transformatorskiej praktyki (wiedzy) wykorzystać fakt, że jesteśmy osadzeni w świecie akademickim jako dość zmarginalizowane - transgresywne? - podmioty, zajmujące równocześnie stosunkowo uprzywilejowaną pozycję społeczną. Bowiem zadanie opozycyjnych akademiczek/akademików nie może polegać, jak to ujmuje amerykańska kulturoznawczyni Rey Chow, na zajmowaniu się własną wiktymizacją w społeczeństwie; ważniejsze jest, by zająć stanowisko wobec „władzy, dobrobytu i przywilejów, które jak na ironię wynikają z "pozycji opozycji" (Chow 1993, 17; tłumaczenie na niemiecki S.H.). Czy możemy zatem być $w$ instytucji nie będąc jej częścią, "członkiem/członkinią, który/która podważa wszystkie zasady członkostwa", jak to określiły Diane Elam i Robyn Wiegman (Elam i Wiegman 1995: 5)?

Obecnie jesteśmy świadkami wielopłaszczyznowych zmian społecznego znaczenia, funkcji, stanowiska i zadań szkolnictwa wyższego i nauki - fundamentalnych zmian materialnych, politycznych i kulturowych w życiu akademickim, które wywierają wpływ na znaczenie wiedzy naukowej, jej tworzenie, rozpowszechnianie i pożytkowanie, a także formują nas na nowo jako podmioty akademickie. Widzimy też, że wiedza feministyczna stała się towarem intelektualnym, stąd rozważanie powyższych pytań staje się coraz bardziej naglące niż kiedykolwiek dotąd. Wciąż jednak brak intelektualnych i instytucjonalnych feministycznych odpowiedzi na transformacje uniwersytetu, które dokładnie opisują Richard Sennet (2010) jako reżimy elastyczności (czyli nieciągłą przebudowę instytucji, elastyczną specjalizację tworzenia i koncentracji władzy bez centralizacji) i Burton Clark (1998) jako „entrepreneurial university" (czyli inkorporację interesów ekonomiczno-technicznych do uniwersytetu, restrukturyzację według menadżerskich modeli regulacyjnych, ustanowienie nowego porządku racjonalności zorientowanego na parametry ekonomiczne).

\footnotetext{
10 Sabine Hark używa angielskiego słowa "sites".
} 
W kontekście tych zmian należałoby, moim zdaniem, pilnie zbadać w jakim stopniu rosnący nacisk na uczelnie wyższe, aby dostosowały przekazywane przez siebie kwalifikacje do potrzeb rynku pracy, zmusza także feminizm akademicki do definiowania się w ramach tego porządku. Na przykład: na jakim etapie profesjonalizacji pozostają obecnie badania nad gender i w jakim stopniu są (jeszcze) „buntem na poziomie ontologii”? Jeśli profesjonalizacja jest zanurzeniem się w określonej dziedzinie, jednostkowym i zbiorowym „procesem socjalizacji ku wyłączności” (Roloff 1993: 222) - jeśli mamy zatem do czynienia z procesami inicjującymi wszelkie zdyscyplinowane sposoby odczuwania, widzenia i rozumienia, z procesami, w których toku nabywa się „nieokreślonych umiejętności i metod postępowania, na przykład technik publicznych wystąpień, które przynależność do danej profesji czynią kompletną" (222), z procesami, które "dzięki powolnemu procesowi dobierania i inicjacji, równoważnej z powtórnymi narodzinami" (Bourdieu 2008: 93) tworzą zgodność, spójność, poczucie przynależności i akceptację ze strony instytucji - to czy profesjonalizacja nie jest tym samym procesem, który za Foucaultem (1993) można rozumieć jako tworzenie "jednostek zdyscyplinowanych"?

Innymi słowy, w procesie socjalizacji akademickiej mamy do czynienia nie tylko z nabywaniem konkretnych umiejętności, które dostarczają narzędzi pracy naukowej. Mamy też do czynienia z formowaniem ich jako specyficzne podmioty habitualizowane związane z instytucją, z inkorporacją „istniejących w głowach" (Bourdieu 1998: 217) społecznych przymusów. Czy nie należałoby zatem zapytać, w ramach dyskusji o profesjonalizacji, która jest obecnie częścią dyskursu feminizmu akademickiego, jakimi podmiotami stajemy się w ramach akademii? Czy nie należałoby koniecznie zapytać, do jakiego stopnia niewątpliwie uzasadniona sprawczość działania - wynikająca z formowania podmiotów jako specyficznych podmiotów habitualizowanych, a dająca szansę na interwencję w danej dziedzinie w celu uzyskania w niej trwałej zmiany, tworzenia własnej wiedzy - oznacza rodzaj uprzedmiotowienia, podporządkowania wobec nieistniejących może, ale na polu gender studies skutecznie oddziałujących warunków i racjonalności? A to prowadzi do kolejnego niezbędnego pytania: jak chcemy być rządzeni?

\section{Postawy graniczne. Czym jest i po co jest krytyka?}

Ale czym właściwie jest krytyka? Jakie jest jej zadanie? Odpowiedzi na to pytanie - w obrębie "»krytycznej« tradycji Zachodu" (Foucault 1996: 178), zajmującej się warunkami "mówienia prawdy", to znaczy tą tradycją myślenia, która, według Michela Foucaulta, zadaje podstawowe pytanie: "kto jest w stanie mówić prawdę" (178) - są, jak wiadomo, rozmaite. W tym sensie należy rozumieć poniższy wywód jako politykę przypomnienia tych odpowiedzi, nie jako próbę udzielania odpowiedzi zupełnie nowych lub podających się za nowe. Pragmatycznym podejściem w tej tradycji krytycznej jest przede wszystkim pogląd Karola Marksa, dla którego krytyka jest zawsze immanentna. Innymi słowy, nie ma żadnego innego stanowiska „poza”: jak mówi Theodor W. Adorno, żyje się „kulturą, którą się krytykuje", jednakże trzeba ją krytykować "bezwzględnie". ${ }^{11}$

\footnotetext{
${ }^{11}$ Cytowane za Demirovic 1999: 672.
} 
Z tym wstępem, chcę wysunąć na pierwszy plan konkretny motyw w refleksji o krytyce jako praktyce, mianowicie motyw postawy granicznej. Określiłam ogólnie krytykę feministyczną jako projekt wyjaśniania relacji między wiedzą, władzą i sposobami istnienia, jako praktykę sprawdzania reżimów zrozumiałości - także własnych - które określają, co można a czego nie można zrealizować. Projekt feministyczny na tym z pewnością się nie kończy, jednak o to właśnie powinno chodzić w krytycznej teorii feministycznej, przy założeniu, że wytyczone przez władzę granice wiedzy są też granicami istnienia, że to wiedza wyznacza granice, w obrębie których potrafiłyśmy i pozwoliliśmy zrozumieć siebie samych, i określa, co można zrealizować, i w jaki sposób rozumieć nasze ciała, doświadczenia, tożsamości - nasze "bycie w świecie" - nawet jeśli celem krytyki feministycznej jest badanie tych granic pod kątem historyczno-praktycznym po to tylko, żeby je przekraczać.

Etos takiego projektu krytyki, umiejscowionego na rozziewie pomiędzy tym, co rzeczywiste, a tym, co możliwe, na styku epistemologii i ontologii, można określić za Foucaultem następująco: „etos filozoficzny" pisze Foucault w Co to jest Oświecenie (2000), polega na krytyce tego, "co [sami] mówimy, myślimy i czynimy, poprzez historyczną ontologię nas samych" (Foucault 2000: 57). Tę właśnie postawę Foucault definiuje jako postawę graniczną, będącą równocześnie trwaniem na granicy i przekraczaniem jej. Zdaniem filozofa nie chodzi tu o odmowę, ale o wyjście poza alternatywę wnętrzezewnętrze i poszukiwanie samych granic. "Krytycyzm”, pisze Foucault, "polega na analizowaniu i namyśle nad ograniczeniami” (57). Krytyka "będzie wydzielała z przygodności, która uczyniła nas tym, czym jesteśmy, możliwość, że nie będziemy już tym, czym jesteśmy, nie będziemy już robić tego, co robimy, myśleć tego, co myślimy" (57).

Foucault nawiązuje tu bezpośrednio do Kanta, który na pytanie, czym jest krytyka, odpowiedział w następujący sposób: krytyka zaczyna się od zakwestionowania absolutnego posłuszeństwa oraz od racjonalnej i refleksyjnej oceny wszystkich obowiązków, nakładanych podmiotom przez państwo foucaultowskie określenie krytyki jako oporu wobec pewnych form urządowienia daje się tu zauważyć równie wyraźnie, jak i butlerowski motyw „buntu na poziomie ontologii".

Zarówno Foucaultowi, jak i Butler chodzi o sprzeciw wobec epistemologicznych norm, decydujących kto może mówić prawdę; o to - żeby posłużyć się najbardziej znanym sformułowaniem Foucaulta by ustalić cenę, za którą podmiot będzie mógł powiedzieć prawdę o sobie samym. Taki sprzeciw wobec norm epistemologicznych jest konieczny, ponieważ, jak często powtarza Butler, nasze epistemologiczne pewniki wspierają określone sposoby organizacji świata, odrzucając alternatywne porządki. W eseju Czym jest krytyka? Esej o cnocie Foucaulta (2002), Butler twierdzi, że pytamy o "granice sposobów poznania, ponieważ żyjąc w obrębie pola epistemologicznego popadamy w jego kryzys". Dzieje się tak dlatego, że "kategorie, którymi jest regulowane życie społeczne, niosą ze sobą pewną niespójność lub całe obszary niewyrażalności" (Butler 2002: 251). 
Tej niespójności kategorii nie można jednak po prostu wykorzystać; stanowisk umożliwiające artykulację nie można, jak wiemy, dowolnie pomnażać, ponieważ władza działa właśnie poprzez ograniczenie ich liczby. Ponadto emancypacyjne projekty wiedzy, żądające tworzenia innej wiedzy, również muszą udowodnić, że przeciwstawiają się mechanizmom samo-zamknięcia się w kategoriach i praktykach rozumienia przez współczesną władzę. Jak można myśleć w sposób dysydencki, skoro władza tworząca porządek obecna jest także w myśleniu krytycznym, skoro dyskursy są zasadniczo organizowane przez praktyki wykluczenia, a wyrażenie możliwości postrzegania zawsze wyklucza inne możliwości postrzegania; w skrócie: skoro to, co jest faktycznie pomyślane i wypowiedziane, zawsze kształtowane jest przez to, czego nie da się (już) pomyśleć i wypowiedzieć? Które praktyki refleksji nad społecznymi i dyskursywnymi warunkami artykulacji, jak też nad zakresem obowiązywania wypowiedzi, są potrzebne, aby zrozumieć, że - jak argumentuje Michel de Certeau - zawsze dokonuje się wyboru pomiędzy tym, "co może być »zrozumiane« [...] [a tym], co winno zostać zapomniane, aby uzyskać przedstawienie teraźniejszej intelligibilności" (de Certeau 2010: 112)?

W kontekście tych powiązań, krytyka jest przede wszystkim zadaniem epistemicznym: jest to krytyka intelektualna, lokalizująca granice wiedzy. Chodzi tu o analizę historii konceptów, o logiczną analizę pojęć, tez i problemów, o genealogię dyskursów i archeologię ich kulturowych podstaw. Innymi słowy chodzi o to, żeby kategorie postrzegania i myślenia - a płeć jest jedną z takich kategorii - które stosujemy z konieczności jako środki poznania, a które są tworzone przez władzę, traktować rygorystycznie jako obiekty poznania. A wszystko po to, aby przejrzeć zamiary "bezkrytycznych przyzwyczajeń umysłu" (Williams 1976: 75) i określić ukryte powiązania władzy, wiedzy i sposobów istnienia, aby wyjaśnić, w jakim stopniu nasze pewniki epistemologiczne wspierają ten sposób organizacji świata, który odrzuca alternatywne porządki istnienia, wiedzy i myślenia.

Aby umożliwić istnienie wiedzy feministycznej w obrębie stworzonych i regulowanych przez władzę instytucji nauki, potrzeba obok krytyki intelektualnej także krytyki społecznej lub instytucjonalnej. Jeśli instytucje nauki równocześnie umożliwiają i ograniczają tworzenie wiedzy feministycznej podporządkowując ją określonemu rygorowi zrozumiałości, który jednocześnie te procesy umożliwia; jeśli feministyczne naukowczynie i feministyczni naukowcy zadomowili się w instytucjach nauki, nawet za cenę dyskomfortu uwikłania się w sprzeczności, i zasadniczo przemieścili się z obrzeży do centrum, to nie można (dłużej) twierdzić, że w stosunku do instytucji nauki są absolutnie "obcy”, zmarginalizowani - że są outsiderami "[korzystającymi] z tego (całkiem negatywnego) przywileju, że nie są zmyleni przez gierki o przywileje, a przynajmniej nie są w nie bezpośrednio uwikłani" (Bourdieu 1997: 169n.). Poza tym nie możemy przyjąć, że "relatywna” obcość w instytucjonalnym, historycznie zdominowanym przez mężczyzn świecie nauki jest wystarczającym źródłem krytycznego dystansu do rzekomych oczywistości środowiska akademickiego.

Świat nauki jest nie tylko zdominowany przez mężczyzn, przez co naukowczynie mogłyby dysponować historycznie uwarunkowaną "naturalną" korzyścią w formułowaniu poglądów - owym słynnym "ostrym spojrzeniem wykluczonych", o którym mówi Bourdieu. Co więcej, świat nauki jest zakon- 
serwowany zaszyfrowanymi relacjami nacechowanymi heteronormatywnością i rasizmem, decydującymi o udziale, uznaniu i autoryzacji.

Aby więc krytyka była skuteczna na poziomie epistemologii tak, żeby wynikł z niej bunt na poziomie ontologii, potrzebna jest krytyka na poziomie władzy, krytyka pytająca o sposoby, jakie instytucje naukowe umożliwiły produkcję wiedzy feministycznej, jednocześnie wytyczając jej granice i powściągając ją; krytyka pytająca zatem, jakie powiązania istnieją pomiędzy określonymi miejscami, obowiązującymi w nich regułami i procedurami, dostępnymi w danym momencie historycznym stanowiskami a produkowaną tam wiedzą. Z grubsza rzecz biorąc, chodzi o przeanalizowanie relacji pomiędzy upozycjonowaniem w przestrzeni społecznej, jej klasyfikacją kulturową i zajęciem stanowisk indywidualno-habitualnych. W tym celu konieczne jest, po pierwsze, usytuowanie podmiotu poznającego w określonym punkcie czasoprzestrzeni; po drugie, wyjaśnienie społecznego uwarunkowania myślenia; i po trzecie, przeanalizowanie społecznej podświadomości, która stała się jednym z narzędzi poznawczych.

W rozmowie zatytułowanej „Krytyczne myślenie jako rozkład doksy” (2005) Loïc Wacquant scharakteryzował te dwie odmiany krytyki jako z jednej strony epistemologiczna krytykę kantowską, z drugiej zaś strony, nawiązując do Marksa, jako krytykę społeczną. Pierwsza odnosi się do badań oceniających kategorie i formy wiedzy w celu określenia ich kognitywnej ważności. Druga o tyle wiąże się z myślą Marksa, że kieruje on „broń rozsądku na rzeczywistość społeczno-historyczną i stawia sobie za zadanie ujawnić ukryte formy dominacji i wyzysku, oraz tworzyć krytykę tak, aby ukazywała alternatywy, które owe formy blokują i wykluczają" (Wacquant 2006: 669). Wacquant twierdzi dalej, że należałoby dokonać wysiłku połączenia krytyki epistemologicznej i społecznej, aby „bezustannie, aktywnie i radykalnie [kwestionować] utarte formy myślenia i tradycyjne formy życia społecznego", czyli "common sense albo dokse (doksa w nawiązaniu do tradycji krytycznej) w tym samym stopniu, co stosunki społeczne i polityczne, obowiązujące w danym momencie historycznym i w danym społeczeństwie" (669).

W charakterystyce krytyki podanej przez Wacquanta również zatem znajdujemy motyw oporu wobec pewnych form urządowienia, impuls, by nie być tak rządzonym, by pogłębić podział pomiędzy tym, co wyobrażalne, a tym, co wyobrażone, pomiędzy tym, co możliwe, a tym, co rzeczywiste. „Wiedza i społeczne determinanty myśli" są nieodzowne, "żeby nas od nich uwolnić i umożliwić nam transcendentowanie świata, jaki jest nam dany, w celu odnalezienia konkretnych projektów przyszłości, różnych od tych wpisanych w porządek rzeczy. Krótko mówiąc, krytyczne myślenie daje nam narzędzia, by świat postrzegać takim, jaki jest i jaki mógtby być" (Wacquant 2006: 669; podkreślenie w oryginale).

Uzyskaliśmy więc w zasadzie odpowiedź na pytanie po co krytyka: krytyka konieczna jest po to, żeby utrzymać rozziew pomiędzy rzeczywistym a możliwym jako wyraz nadziei, że nie wszystko musi pozostać tak, jak jest. Z całą świadomością heteronomii każdej podmiotowości, chodzi o to, by 
nieustanie generować nowe sposoby rządzenia sobą i bycia rządzonym, by wynajdować nowe sposoby istnienia. Ostateczną odpowiedź zostawmy na razie Karolowi Marksowi. W roku 1843 napisał on do Arnolda Rugego:

[...] na tym właśnie polega przewaga nowego kierunku, że nie usiłujemy w sposób dogmatyczny antycypować przyszłości, lecz chcemy dopiero poprzez krytykę starego świata odkryć nowy. [...] Możemy więc kierunek naszego pisma wyrazić w jednym zdaniu: praca naszej epoki nad wyjaśnieniem sobie samej (krytyczna filozofia) sensu własnych walk i pragnień. Jest to praca dla świata i dla nas. Może ona być tylko dziełem zjednoczonych sił. (Marks 1960: 416, 419; podkreślenie w oryginale)

Ttumaczenie: Anna Kasten ${ }^{12}$

\section{Bibliografia}

Bourdieu, Pierre. 1997. Die männliche Herrschaft. w: (red.) Dölling, Irene, Krais, Beate. Ein alltägliches Spiel. Geschlechterkonstruktion in der sozialen Praxis. Frankfurt am Main: Suhrkamp, s. 153-217.

Bourdieu, Pierre. 1998. Vom Gebrauch der Wissenschaft. Für eine klinische Soziologie des wissenschaftlichen Feldes. Konstanz: UVK.

Bourdieu, Pierre. 2008. Zmyst praktyczny. Tłum. Maciej Falski. Kraków: Wydawnictwo Uniwersytetu Jagiellońskiego.

Butler, Judith. 2002. Was ist Kritik? Ein Essay über Foucaults Tugend. W: „Deutsche Zeitschrift für Philosophie" 50/2, s. 149-165.

Butler, Judith. 2005. Gefährdetes Leben. Frankfurt am Main: Suhrkamp.

Certeau, de Michel. 2010. Pismo historii. Tłum. Krzysztof Jarosz. W: „Er(r)go. Teoria, Literatura, Kultura" 20/21, 1-2, s. 109-137.

Chow, Rey. 1993. Writing Diaspora: Tactics of Intervention in Contemporary Cultural Studies. Bloomington: Indiana University Press.

Clark, Burton R. 1998. Creating Entrepreneurial Universities. Organizational Pathways of Transformation. Surrey: Pergamon Press.

Demirovic, Alex. 1999. Der nonkonformistische Intellektuelle. Die Entwicklung der Kritischen Theorie zur Frankfurter Schule. Frankfurt am Main: Suhrkamp.

Douglas, Mary. 2011. Jak myśla instytucje. Tłum. Olga Siara. Warszawa: Wydawnictwo Naukowe PWN.

\footnotetext{
12 Za cenne uwagi do tego przekładu tekstu dziękuję Agnieszce Kowaluk. Za krytyczną lekturę mojego przekładu również dziękuję Redakcji „InterAlia” oraz za jej zaangażowanie w umożliwieniu opublikowania tego tekstu. (Anna Kasten, tłumaczka)
} 
Elam, Diane, Wiegman, Robyn. 1995. Contingencies. W: (red.) idem. Feminism Beside Itself. London, New York: Routledge, s. 1-8.

Foucault, Michel. 1971. Die Ordnung der Dinge. Frankfurt am Main: Suhrkamp.

Foucault, Michel. 1993. Nadzorować i karać. Narodziny więzienia. Tłum. Tadeusz Komendant. Warszawa: ALETHEIA.

Foucault, Michel. 1996. Diskurs und Wahrheit. Berlin: Merve.

Foucault, Michel. 2000. Co to jest oświecenie? Tłum. Agata Sypniewska. W: „Odra "7-8, s. 49-59.

Genschel, Corinna. 2002. Queer Meets Trans Studies: Über den problematischen Stellenwert geschlechtlicher Transgressionen in Queer Theorie. W: „Freiburger Frauenstudien“ 12, s. 163186.

Hark, Sabine. 2005. Dissidente Partizipation. Eine Diskursgeschichte des Feminismus. Frankfurt am Main: Suhrkamp.

Hawkesworth, Mary. 2004. The Semiotics of Premature Burial: Feminism in a Postfeminist Age. W: "Signs. Journal of Women in Culture and Society" vol. 29 nr 4, s. 961-986.

Kahlert, Heike. 2001. (K)ein Fach wie jedes andere? Feministische Lehre im Professionalisierungsprozeß. W: "Die Philosophin” 12/23, s. 74-92.

Laclau, Ernesto, Mouffe, Chantal. 2007. Hegemonia i socjalistyczna strategia. Przyczynek do projektu radykalnej polityki demokratycznej. Tłum. Sławomir Królak. Wrocław: Wydawnictwo Naukowe Dolnośląskej Szkoły Wyższej Edukacji TWP.

Marks, Karol. 1960. Marks do Rugego. W: Marks, Karol, Engels, Fryderyk (red.): Dzieła. Tom 1. Tłum. Konstanty Jażdżewski. Warszawa: Książka i Wiedza, s. 408-419.

McRobbie, Angela. 2004. Wozu Mütter und Väter? Judith Butler, Antigones Verlangen. Verwandtschaft zwischen Leben und Tod. Neuordnung der Verwandtschaftsverhältnisse, Verwerfung des Feminismus. W: "Das Argument" 252, s. 648-657.

McRobbie, Angela. 2008. The Aftermath of Feminism. Los Angeles, London: Sage.

Raunig, Gerald. 2008. Was ist Kritik? Aussetzung und Neuzusammensetzung in textuellen und sozialen Maschinen. Online na: http://eipcp.net/transversal/0808/raunig.

Roloff, Christine. 1993. Hochqualifizierte Frauen in Naturwissenschaft und Technik - Ursachen ihrer Marginalität und Strategien zur Veränderung. W: „WSI-Mitteilungen” 4, s. 220-229.

Sennett, Richard. 2010. Kultura nowego kapitalizmu. Tłum. Grzegorz Brzozowski, Karol Osłowski. Warszawa: Muza.

Wacquant, Loïc. 2006. Kritisches Denken als Zersetzung der Doxa. W: (red.) Bittlingmayer, Uwe, Bauer, Ullrich. Die Wissensgesellschaft: Mythos, Ideologie oder Realität. Wiesbaden: VS, s. 669674.

Willliams, Raymond. 1976. Keywords: A Vocabulary of Culture and Society. New York: Oxford University Press.

Woolf, Virginia. 2002. Własny pokój. Trzy gwinee. Tłum. Ewa Krasińska. Warszawa: Sic!. 
What is critique and what is it for? On the potential and limits of feminist critique today

The article is constitutes a philosophical reflection on the potential of contemporary feminist critical theory. The author understands feminist critique as a project aimed at elucidating the relations between knowledge, power, and ways of being - and as the practice of testing the regimes of intelligibility that dictate what is and what is not realizable.

Keywords: feminism, critique, regimes of intelligibility, power, knowledge, ways of being, exclusion, recognition 